\title{
Updates to the Canadian Immunization Guide: March 2014 to March 2015
}

\author{
Gemmill I, ${ }^{1,2}$ and Quach $\mathrm{C}^{3,4}$, on behalf of the National Advisory Committee on Immunization* \\ ${ }^{1}$ Chair, National Advisory Committee on Immunization \\ ${ }^{2}$ Kington, Frontenac and Lennox \& Addington, Public Health, Kingston, ON \\ ${ }^{3} \mathrm{NACl}$ Co-Chair and Pneumococcal Working Group Chair, Montréal, QC \\ ${ }^{4}$ Vaccine Study Centre, McGill University Health Centre, Montréal, QC \\ "Correspondence: naci-ccni@phac-aspc.gc.ca
}

\begin{abstract}
The National Advisory Committee on Immunization (NACl) develops recommendations for the use of vaccines for Canadians, which are summarized in the Canadian Immunization Guide (the Guide) and which is updated on a regular basis. Between March 2014 and February 2015 recommendations on five vaccines have been issued. Updates to the Guide include recommendations made for the alternative dosing administration of the human papillomavirus (HPV) vaccine in adolescents, timing of varicella zoster immune globulin (Varlg) following exposure to varicella, and the meningococcal and quadrivalent influenza vaccines, recently authorized for use in Canada. A change in recommendations for the use of pneumococcal vaccines in adults and individuals with asthma has also been made. The chapter on tick-borne encephalitis vaccine has now been removed from the Guide as this vaccine is no longer available in Canada.
\end{abstract}

\section{Introduction}

The National Advisory Committee on Immunization (NACl) develops recommendations for the use of vaccines for Canadians and is the scientific advisory body on immunization for the Public Health Agency of Canada (PHAC) (1). These recommendations and other immunization information are published in the Canadian Immunization Guide (the Guide) (2).

Since 1979, the Guide has been a trusted, reader-friendly summary of information that has been used by health care providers to give advice on immunization to their patients, and by policy makers for the delivery of immunization programs. The document consists of five parts, covering key immunization information, vaccine safety, special populations, active vaccines, and passive immunization agents. Since the 2006 edition, the Guide has undergone extensive revisions. In 2012, it began to be published online in an evergreen electronic format (2). The objective of this article is to highlight updates to the Guide, which have been made between March 1, 2014, and March 31, 2015.

\section{Approach}

When developing its statements, $\mathrm{NACl}$ conducts comprehensive knowledge syntheses and analyses incorporating scientific reviews, evolving practices, and national and international recommendations. NACl then reflects its recommendations in a summarized format in the corresponding chapters of the Guide. Detailed recommendations concerning immunization and the use of vaccines available in Canada can be found in the $\mathrm{NACl}$ Statements and Statement Updates, which are available on the PHAC website (1). 


\section{Summary of updates}

Table 1 provides a summary of recent changes and additions to the Guide.

\section{Table 1: Highlights of key changes to active vaccine recommendations in the Canadian Immunization} Guide, March 2014 to March 2015

\begin{tabular}{|c|c|}
\hline \multirow[t]{2}{*}{ Human papillomavirus } & $\begin{array}{l}\text { For immunocompetent, non-HIV infected, adolescents } 9 \text { to } 14 \text { years of age, NACl now } \\
\text { recommends either a two- (HPV2 or HPV4 at months } 0 \text { and } 6-12) \text { or three- (HPV2 } \\
\text { vaccine at months } 0,1 \text {, and } 6 \text { or HPV4 vaccine at months } 0,2 \text {, and } 6 \text { ) dose schedule. }\end{array}$ \\
\hline & $\begin{array}{l}\text { A three-dose schedule of the HPV vaccine (HPV4 for males and females-0, } 2,6 \text { months; } \\
\text { or HPV2 for females- }-1,6 \text { months) is recommended for individuals who are } \\
\text { immunocompromised and immunocompetent HIV-infected individuals. }\end{array}$ \\
\hline \multirow[t]{3}{*}{ Influenza } & $\begin{array}{l}\text { Two quadrivalent inactivated influenza vaccines (QIV) have been authorized for use in } \\
\text { Canada (Flulaval }{ }^{\mathrm{TM}} \text { Tetra and Fluzone }{ }^{\circledR} \text { Quadrivalent). }\end{array}$ \\
\hline & $\begin{array}{l}\text { Egg-allergic individuals may be vaccinated against influenza in any settings where } \\
\text { vaccines are routinely administered using trivalent inactivated influenza (TIV) or QIV } \\
\text { without a prior influenza vaccine skin test and with the full dose. }\end{array}$ \\
\hline & $\begin{array}{l}\mathrm{NACI} \text { recommends preferential use of live attenuated influenza vaccine (LAIV), where } \\
\text { available, in children younger than } 6 \text { years of age based on evidence of superior efficacy } \\
\text { of LAIV compared to TIV in these children, with weaker evidence of superior efficacy in } \\
\text { older children. Although it is anticipated that the superior efficacy for LAIV over TIV } \\
\text { extends beyond age } 6 \text { years, the evidence does not indicate at which specific age the } \\
\text { efficacies of LAIV and TIV become equivalent. If LAIV is not available for those for whom } \\
\text { it is considered superior, TIV should be used. }\end{array}$ \\
\hline \multirow[t]{3}{*}{ Meningococcal } & $\begin{array}{l}\text { Two new meningococcal inactivated vaccines have been authorized for use in Canada: } \\
\text { multicomponent meningococcal serogroup } B\left(4 C M e n B \text {, Bexsero }{ }^{\mathrm{TM}} \text { ) and meningococcal }\right. \\
\mathrm{A}, \mathrm{C}, \mathrm{Y} \text {, and } \mathrm{W}-135 \text { conjugate (Nimenrix }{ }^{\mathrm{TM}} \text { ) vaccine. }\end{array}$ \\
\hline & $\begin{array}{l}\mathrm{NACl} \text { recommends immunization with } 4 \mathrm{CMenB} \text { vaccine for individuals } 2 \text { months of age } \\
\text { and older who are: } \\
\text { - } \quad \text { at high risk of invasive meningococcal disease (IMD) caused by serogroup B } \\
\text { - Neisseria meningitidis } \\
\text { in close contact with a case of IMD caused by serogroup B Neisseria } \\
\text { meningitidis } \\
\text { - at risk during IMD outbreaks caused by serogroup B Neisseria meningitidis }\end{array}$ \\
\hline & $\begin{array}{l}\text { For high-risk individuals } 2 \text { years of age and older or for travellers } 2 \text { years of age and older } \\
\text { going to areas where the meningococcal vaccine is recommended, any of the conjugate } \\
\text { quadrivalent }(A, C, Y \text {, and } W-135) \text { products can be used. }\end{array}$ \\
\hline \multirow[t]{2}{*}{ Pneumococcal } & $\begin{array}{l}\mathrm{NACl} \text { recommends vaccination with an age-appropriate pneumococcal vaccine for } \\
\text { individuals who required medical attention for asthma in the past } 12 \text { months. }\end{array}$ \\
\hline & $\begin{array}{l}\text { Individuals with medical conditions putting them at high risk of IPD should receive one } \\
\text { lifetime booster dose of Pneu-P-23 } 5 \text { years after the previous one, regardless of age at } \\
\text { first dose. }\end{array}$ \\
\hline
\end{tabular}




\begin{tabular}{|c|c|}
\hline & $\begin{array}{l}\text { One dose of pneumococcal polysaccharide (Pneu-P-23) vaccine is recommended for all } \\
\text { adults } 65 \text { years of age and older as long as } 5 \text { years has passed since any previous Pneu- } \\
\text { P-23 dose, and for immunocompetent adults less than } 65 \text { years of age in long-term care } \\
\text { facilities, or who have conditions putting them at increased risk of pneumococcal disease. }\end{array}$ \\
\hline & $\begin{array}{l}\text { All individuals who have previously received Pneu-P-23 vaccine and require re- } \\
\text { immunization with pneumococcal conjugate (Pneu-C-13) vaccine should receive Pneu-C- } \\
13 \text { vaccine no sooner than five years after the most recent dose of Pneu-P-23. }\end{array}$ \\
\hline & $\begin{array}{l}\text { Pneu-C-13 should be administered to adults with immunocompromising conditions, } \\
\text { followed by Pneu-P-23 at least eight weeks after-if not already administered. }\end{array}$ \\
\hline Tick-borne encephalitis & Tick-borne encephalitis vaccine is no longer available in Canada. \\
\hline Varicella & $\begin{array}{l}\text { For maximal benefit, varicella zoster immune globulin (Varlg) should be administered as } \\
\text { soon as possible after exposure, ideally within } 96 \text { hours after first exposure, but can be } \\
\text { administered up to } 10 \text { days after last exposure. }\end{array}$ \\
\hline
\end{tabular}

\section{Conclusion}

Since 2012, the Guide has been continuously updated to incorporate new science and practices as reflected in the most recent $\mathrm{NACl}$ Statements and $\mathrm{NACl}$ Statement Updates. NACl and the Public Health Agency of Canada are committed to providing information on immunization and vaccines available for use in Canada in an easily accessible, reader-friendly format, through timely and ongoing updates of the Guide.

\section{Acknowledgements}

The authors would like to thank the extremely dedicated members of National Advisory Committee on Immunization and the Public Health Agency of Canada staff who are supporting the Canadian Immunization Guide update process.

\section{Conflict of interest}

None

\section{References}

(1) National Advisory Committee on Immunization. NACI Statements, Recommendations and Updates. 2015. http://www.phac-aspc.gc.ca/naci-ccni.

(2) National Advisory Committee on Immunization. Canadian Immunization Guide. 2015. http://www.phac-aspc.gc.ca/publicat/cig-gci/. 